\title{
Synthesis of the suspected trans-11,cis-13 conjugated linoleic acid isomer in ruminant mammary tissue by FADS3-catalyzed $\Delta 13$-desaturation of vaccenic acid
}

\author{
Cyrielle Garcia, ${ }^{*}$ Cécile Duby, ${ }^{*}$ Daniel Catheline, ${ }^{*}$ Pablo G. Toral, $†$ Laurence Bernard, $†$ Philippe Legrand, * \\ and Vincent Rioux*1 \\ *Laboratoire de Biochimie Agrocampus Ouest-INRA, USC1378, 35000 Rennes, France \\ †INRA, UR1213 Herbivores, 63122 Saint-Genès-Champanelle, France
}

\begin{abstract}
The octadecadienoic conjugated linoleic acid (CLA) isomer with trans-11 and cis-13 double bonds (trans11,cis-13 CLA) has been described in ruminant milk. For now, this specific CLA is suspected to derive exclusively from ruminal biohydrogenation of dietary $\alpha$-linolenic acid. However, in rodents, the fatty acid desaturase 3 (FADS3) gene was recently shown to code for an enzyme able to catalyze the unexpected $\Delta 13$ desaturation of vaccenic acid, producing a $\Delta 11,13$-CLA with all the structural characteristics of the trans11,cis-13 isomer, although no commercial standard exists for complete conclusive identification. Because the FADS3 gene has already been reported in bovine animals, we hypothesized in the present study that an alternative direct FADS3-catalyzed $\Delta 13$-desaturation of vaccenic acid in mammary tissue may therefore coexist with $\alpha$-linolenic acid biohydrogenation to explain the final ruminant milk trans-11,cis-13 CLA presence. Here, we first confirm that the FADS3 gene is present in ruminant mammal genomic sequence databases. Second, we demonstrate that the $\Delta 11,13$-CLA found in milk fat and the highly probable trans-11,cis-13 CLA isomer produced by rodent FADS3 possess exactly the same structural characteristics. Then, we show that bovine mammary MAC-T and BME-UV epithelial cells express both FADS3 and stearoyl-CoA desaturase 1 (SCD1) mRNA and are able to synthesize both the suspected trans-11,cis-13 CLA and cis-9,trans-11CLA (rumenic acid) isomers when incubated with vaccenic acid. Finally, the concomitant presence of the suspected trans-11,cis-13 CLA isomer with FADS3 mRNA was shown in goat mammary tissue, whereas both were con-
\end{abstract}

Received June 6, 2016.

Accepted October 2, 2016.

${ }^{1}$ Corresponding author: vincent.rioux@agrocampus-ouest.fr versely very low or even absent in goat liver. Therefore, this study provides several lines of evidence that, by analogy with rumenic acid, trans-11,cis-13 CLA may originate both from ruminal biohydrogenation and from direct FADS3-catalyzed $\Delta 13$-desaturation of vaccenic acid in mammary tissue.

Key words: vaccenic acid, trans-11,cis-13 conjugated linoleic acid, fatty acid desaturase 3, stearoyl-CoA desaturase 1

\section{INTRODUCTION}

Conjugated linoleic acid isomers consist of a group of octadecadienoic acids (18:2) with double bond pairs differing by position and geometrical configuration (Palmquist et al., 2005). In ruminant milk, rumenic acid (cis-9,trans-11 CLA) is by far (70-90\% of total CLA isomers) the most predominant isomer (Lock and Bauman, 2004). Rumenic acid derives partly from ruminal biohydrogenation of linoleic acid (18:2n-6) and mainly from endogenous host $\Delta 9$-desaturation of vaccenic acid (trans-11-18:1 or VA; Griinari et al., 2000), itself produced as an intermediate from linoleic and $\alpha$-linolenic acid (18:3n-3) ruminal hydrogenation (Harfoot and Hazlewood, 1997; Jenkins et al., 2008).

In studies quantifying milk CLA, the trans-7,cis-9 (Corl et al., 2002; Piperova et al., 2002; Shingfield et al., 2008a) and the trans-11,cis-13 (Sehat et al., 1999; Kraft et al., 2003; Luna et al., 2005) are described as the second most prevalent isomers. The trans-7,cis-9 CLA is thought to be exclusively synthesized by the action of tissue $\Delta 9$-desaturase on trans-7-18:1, which is produced in the rumen (Corl et al., 2002). By contrast, the trans-11,cis-13 CLA is for now suspected to be exclusively of rumen origin (Lock and Bauman, 2004). Ruminal biohydrogenation (Figure 1) can indeed convert dietary $\alpha$-linolenic acid (cis-9,cis-12,cis-15-18:3, or 18:3n-3) to cis-9, trans-11, cis-15-conjugated triene (Harfoot and Hazlewood, 1997; Jenkins et al., 2008), which 


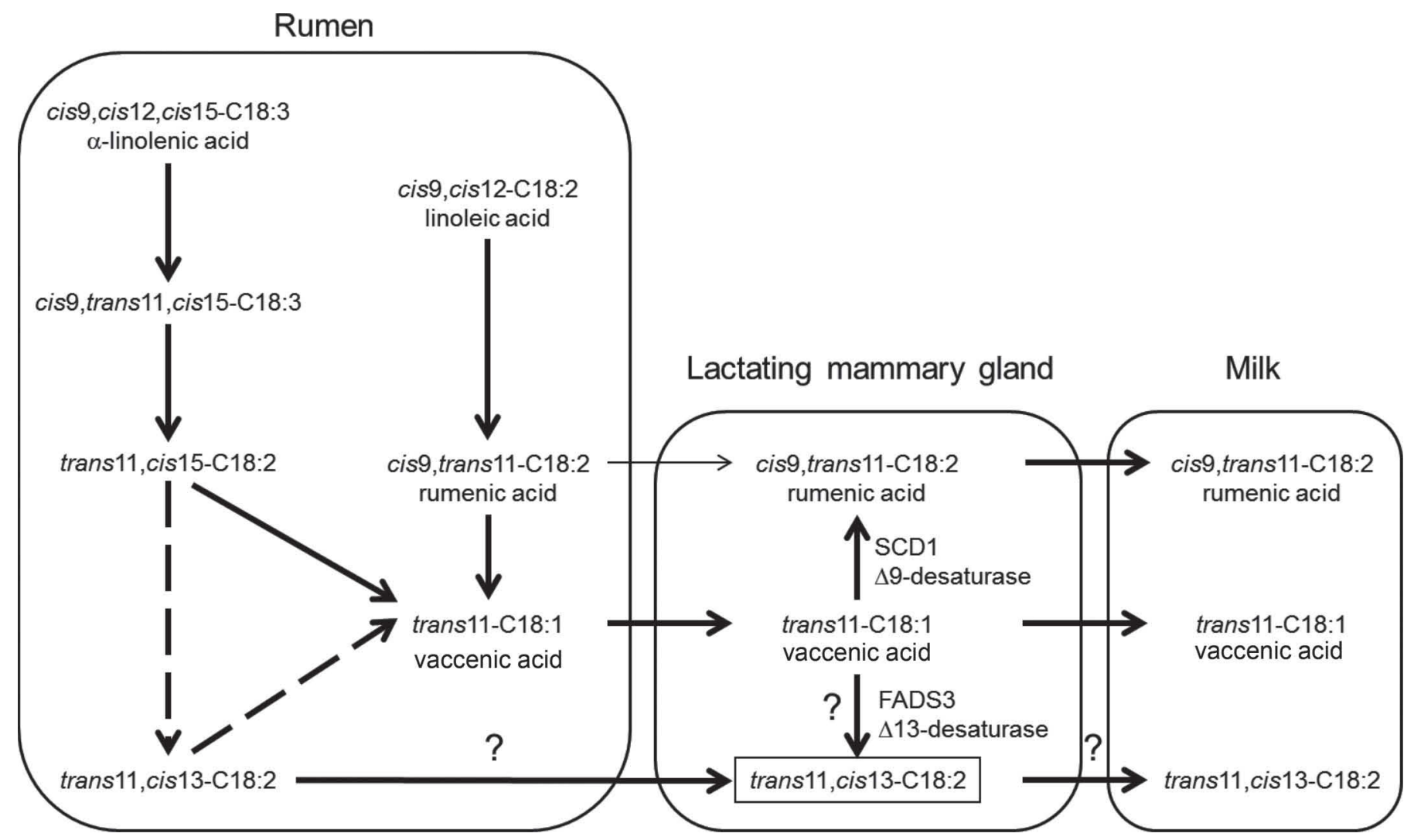

Figure 1. Suspected metabolic pathways leading to the presence of suspected trans-11,cis-13 CLA in ruminant milk. Ruminal biohydrogenation can convert dietary $\alpha$-linolenic acid (cis-9,cis-12,cis-15-18:3) to cis-9,trans-11,cis-15-conjugated triene, which is subsequently metabolized to trans-11,cis-15-18:2 by incomplete bacteria hydrogenation. The step corresponding to the isomerization of trans-11,cis-15-18:2 to trans11, cis-13 CLA has been shown to be catalyzed in vitro by specific Butyrivibrio fibrisolvens strains but still remains speculative in vivo. As recently shown in rodents, this fatty acid may also come directly from vaccenate $\Delta 13$-desaturation catalyzed by fatty acid desaturase 3 (FADS3).

is subsequently metabolized to trans-11,cis-15-18:2 by incomplete bacteria hydrogenation. The last step corresponding to the isomerization of trans-11,cis-15-18:2 to trans-11,cis-13 CLA has been shown to be catalyzed in vitro by specific Butyrivibrio fibrisolvens strains (Fukuda et al., 2009) but still remains speculative in vivo. In addition to milk, the minor presence of the trans11,cis-13 CLA isomer has been described in the digesta (Shingfield et al., 2008b; Toral et al., 2010; Shen et al., 2011) and subcutaneous adipose tissue (Dugan et al., 2007; Petri et al., 2014) of ruminants.

So far, this specific trans-11,cis-13 CLA isomer has not drawn too much attention, for the following reasons. First, its separation from other CLA isomers present in biological samples (dairy products) remains a considerable analytical challenge (De la Fuente et al., 2006; Christie et al., 2007). Second, no standard of the trans-11,cis-13 CLA is commercially available (Sehat et al., 1998, 1999), whereas a commercial mixture of cis11,trans-13, cis-11,cis-13, and trans-11,trans-13 CLA is available (Rioux et al., 2013). Third, great varia- tions of its amount (0.07-8.00\% of total isomers) are reported (Lock and Bauman, 2004). Finally, no function is known for this CLA isomer although it might be physiologically important like other isomers such as cis-9,trans-11 or trans-10,cis-12 (Wahle et al., 2004).

Yet, in rodents, the fatty acid desaturase 3 (FADS3) gene was recently shown to code for an enzyme able to catalyze the $\Delta 13$-desaturation of VA (Rioux et al., 2013). Structural characterization of the $\Delta 11,13$ CLA produced by this FADS3-catalyzed desaturation strongly suggested that it was the trans-11,cis-13 CLA isomer. Because the FADS 3 gene has been described in the genomic sequence of the FADS (fatty acid desaturase) gene cluster in cattle (Park et al., 2009; Taniguchi et al., 2014), we hypothesized in the present study that, by analogy with the dual origin of rumenic acid, an alternative and direct host FADS3-catalyzed $\Delta 13$ desaturation of VA (Figure 1) may therefore co-exist with incomplete ruminal biohydrogenation of 18:3n-3 to explain the final presence of the trans-11,cis-13 CLA in ruminant milk fat. 
MATERIALS AND METHODS

\section{Bovine Mammary Epithelial Cell Culture and Incubation with VA}

Bovine MAC-T and BME-UV mammary epithelial cells were kindly provided by F. Dessauge (UMR Pegase, INRA Saint-Gilles, France). The BME-UV cells were grown in 5:3:2 ( $\mathrm{vol} / \mathrm{vol} / \mathrm{vol}$ ) mixture of Dulbecco's modified Eagle medium-F12/RPMI-1640/ NCTC35 supplemented with $10 \%$ fetal bovine calf serum, $1 \%$ lactose, $0.5 \%$ lactalbumin hydrolysate, 1.2 $\mathrm{m} M$ L-glutathione reduced, $10 \mu \mathrm{g} / \mathrm{mL}$ L-ascorbic acid, $5 \mu \mathrm{g} / \mathrm{mL}$ of holo-transferrin, $1 \mu \mathrm{g} / \mathrm{mL}$ of hydrocortisone and insulin, $0.5 \mu \mathrm{g} / \mathrm{mL}$ of progesterone, and $1 \%$ penicillin/streptomycin. The MAC-T cells were grown in Dulbecco's modified Eagle medium supplemented with $10 \%$ fetal bovine calf serum, $5 \mu \mathrm{g} / \mathrm{mL}$ insulin, and $1 \%$ penicillin/streptomycin.

The ability of the bovine FADS3 protein to $\Delta 13$ desaturate VA was investigated by incubating the cells with VA (Sigma, Saint-Quentin-Fallavier, France) and $\left[1-{ }^{13} \mathrm{C}\right]-\mathrm{VA}$ (chemical purity $95 \%$, isotopic enrichment $99 \%$, synthesized by the Commissariat à l'Energie Atomique, CEA, Gif-sur-Yvette, France) (Loreau et al., 2000). Incubations with cis-11-18:1, cis-9-18:1, and cis-9,trans-11 CLA were also realized. Fatty acid (FA) albuminic complexes were prepared as described (Rioux et al., 2000). The final FA concentration of the incubation medium was $200 \mu M$ (unless indicated otherwise) and albumin concentration was $150 \mu M$, leading to a FA:albumin molar ratio of 1.3:1. The incubation was initiated by replacing the culture medium with the FAcontaining medium. Incubation was then carried out for $24 \mathrm{~h}$ at $37^{\circ} \mathrm{C}$ in a $5 \% \mathrm{CO}_{2}$ atmosphere.

\section{Fatty Acid Analysis}

Cellular lipids were extracted with hexane-isopropanol $(3: 2, \mathrm{vol} / \mathrm{vol})$ after acidification with $1 \mathrm{~mL} \mathrm{HCl} 3$ $M$, as described (Rioux et al., 2015). After saponification for $15 \mathrm{~min}$ at $70^{\circ} \mathrm{C}$ with $1 \mathrm{~mL}$ of $0.5 \mathrm{M} \mathrm{NaOH}$ in methanol, $\mathrm{FA}$ were methylated with $\mathrm{BF}_{3}(14 \%$ in methanol) at $70^{\circ} \mathrm{C}$ for $10 \mathrm{~min}$. The FAME were extracted with pentane and analyzed by GC-MS using an Agilent Technologies 7890N (Bios Analytic, Santa Clara, CA) with a bonded silica capillary column $(60$ $\mathrm{m} \times 0.25 \mathrm{~mm}$; BPX 70; SGE). Helium was used as carrier gas (average velocity $24 \mathrm{~cm} / \mathrm{s}$ ). The column temperature program started at $150^{\circ} \mathrm{C}$, gradually increased at $2^{\circ} \mathrm{C} / \mathrm{min}$ to $220^{\circ} \mathrm{C}$, and held at $220^{\circ} \mathrm{C}$ for 10 min. Mass spectra were recorded with an Agilent Technologies 5975C inert MSD with triple axis detector.
The mass spectrometer was operated under electron impact ionization conditions (electron energy $70 \mathrm{eV}$, source temperature $230^{\circ} \mathrm{C}$ ). Data were obtained in scan mode with a mass range of $m / z 50-550$ atomic mass units (amu). Identification of the FAME was based upon retention times $\left(\mathbf{R}_{\mathrm{t}}\right)$ obtained for methyl ester of authentic standards, when available. The commercial FA used as standards were rumenic acid (cis-9,trans-11 CLA), a mixture of cis-11,trans 13 , cis-11,cis-13, and trans-11,trans13 CLA (Matreya, Pleasant Gap, PA), and pure trans-11,trans 13 CLA (Larodan, Malmö, Sweden). The National Institute of Standards and Technology database (version 2.0) was also sometimes used to identify unknown FA.

\section{Identification of CLA After Their Conversion to 4,4-Dimethyloxazoline Derivatives}

To confirm the identity of CLA isomers, FAME were first pre-concentrated by separation on preparative silver ion thin layer chromatography using silicagel $\mathrm{H}$ impregnated with $10 \%$ (wt/wt) $\mathrm{AgNO}_{3}$. Separation was performed according to the number and configuration of double bonds, using a mixture of 90/10 ( $\mathrm{vol} / \mathrm{vol}$ ) hexane/diethylether for development. At the end of the chromatographic runs, the plates were sprayed with a solution of $10 \mathrm{mg}$ per $100 \mathrm{~mL}$ of primuline in acetone (Sigma, Saint-Quentin-Fallavier, France) and visualized under UV light. Bands corresponding to CLA according to a standard of methylated rumenic acid, were scraped off and transferred into a test tube. Collected CLA were then converted to 4,4-dimethyloxazoline (DMOX) derivatives (Guillou et al., 2003; Rioux et al., 2013, 2015) and analyzed by GC-MS in electron impact ionization mode. Briefly, a mild 2-step reaction was used for preparing DMOX. The FAME in dichloromethane $(1 \mathrm{~mL})$ were converted to corresponding amides by incubation at $45^{\circ} \mathrm{C}$ for 30 min with $200 \mu \mathrm{L}$ of 2-amino-2-methyl-1-propanol and $100 \mu \mathrm{L}$ of potassium tert-butoxide in tetrahydrofuran $(2: 1 \mathrm{vol} / \mathrm{vol})$. The resulting 2-(methylpropanol) amides were isolated by partition between hexane/diethylether $(50 / 50 \mathrm{vol} / \mathrm{vol})$ and water, and then converted to DMOX by treatment with trifluoroacetic anhydride under mild conditions $\left(50^{\circ} \mathrm{C}\right.$ for $\left.45 \mathrm{~min}\right)$. The column, gas vector, and detector were similar to those used for the analysis of FAME (see above).

\section{Identification of CLA After Their Reaction with 4-Methyl-1,2,4-Triazoline-3,5-Dione}

To further confirm the identity of minor CLA isomers, thin layer chromatography pre-concentrated CLA were 
also converted to Diels-Alder adducts (Berdeaux et al., 1997; Dobson, 1998) by reaction with 4-methyl-1,2,4triazoline-3,5-dione (MTAD). The CLA in dichloromethane were mixed with MTAD $(1 \mathrm{mg} / \mathrm{mL}$, Santa Cruz Biotechnology, Santa Cruz, CA) at $0^{\circ} \mathrm{C}$ for $10 \mathrm{~s}$. The reaction was stopped immediately by addition of a 5 -fold excess of 1,3-hexadiene (Santa Cruz Biotechnology). The MTAD adducts were analyzed by GC-MS using the same BPX70 column as for FAME analysis but with a temperature gradient starting at $150^{\circ} \mathrm{C}$, then gradually increasing at $10^{\circ} \mathrm{C} / \mathrm{min}$ to $260^{\circ} \mathrm{C}$, and holding at $260^{\circ} \mathrm{C}$ for $90 \mathrm{~min}$.

\section{RNA Isolation and Quantitative Reverse- Transcription PCR}

Total RNA was extracted from cells with Trizol (Invitrogen). The RNA was converted into cDNA with the IScript cDNA synthesis kit (Bio-Rad, Hercules, CA). The RNA was quantified by Real-Time PCR with the Taqman Universal PCR Master Mix (Applied Biosystem) containing $40 \mathrm{ng}$ of retrotranscripted RNA, 0.5 $\mu M$ primers, and $0.25 \mu M$ Taqman probe. Primers and 5'-FAM/TAMRA-3' Taqman probes specific to caprine and bovine desaturase genes are described in Table 1. Amplification was performed by a CFX 96 real-time PCR Detection System (Bio-Rad) over 40 cycles of $95^{\circ} \mathrm{C}$ for $15 \mathrm{~s}$ and $60^{\circ} \mathrm{C}$ for $1 \mathrm{~min}$ (Ramakers et al., 2003). The $18 S$ gene expression was quantified as an endogenous control using the 18S RNA Control kit Yakima-Yellow Eclipse Dark Quencher (Eurogentec, Liège, Belgium) and relative gene expression was determined from the cycle thresholds $(\mathrm{Ct})$ using the $2^{-\Delta \mathrm{Ct}}$ method.

\section{Lactating Goat Tissue Samples}

Samples of the mammary secretory tissue and liver were collected from 8 multiparous nonpregnant lactating Alpine goats. The experimental design of this study has been previously published (Bernard et al., 2010; Toral et al., 2013). The FA composition of mammary tissue and liver samples was re-evaluated in the present study using the GC-MS methodology described above, with special focus on the suspected trans-11, cis-13 CLA. The quantitative reverse-transcription PCR was carried out on mammary tissue and liver mRNA samples using specific primers and probes for goat FADS1, FADS2, FADS3, and stearoyl-CoA desaturase 1 (SCD1; Table 1).

\section{Expression of Results and Statistical Analysis}

All data values shown represent the mean \pm standard deviation or standard error of the mean for the number of replicates (n) indicated in each figure legend. Student's $t$-test was used to determine the statistical significance between groups, where indicated.

\section{RESULTS AND DISCUSSION}

\section{Presence of the FADS3 Gene Within the FADS Cluster in Ruminant Species}

The FADS3 gene was first described in humans, within the genomic structure of the FADS gene cluster, which also includes FADS1 ( $\triangle 5$-desaturase) and FADS2 ( $\Delta 6$-desaturase) genes and is located in chromosome 11 (Marquardt et al., 2000). Since then, FADS3 orthologs similarly clustered with FADS1 and FADS2 have been identified in rat chromosome 1 (Pedrono et al., 2010), pig chromosome 2 (Taniguchi et al., 2014), baboon chromosome 14 (Park et al., 2009), mouse chromosome 19 (Nakamura and Nara, 2004), and cattle chromosome 29 (Park et al., 2009; Taniguchi et al., 2014). In the present study, genomic database searches in other ruminant species revealed the presence of the FADS1/ FADS2/FADS3 gene cluster with similar order and direction in caprine (chromosome 29, NC_022321.1, Capra hircus) and ovine (chromosome 21, NC_019478.1, Ovis aries) species, FADS3 being located tail-to-tail with FADS2 (Marquardt et al., 2000). In ruminant species, the exon/intron organization of the FADS3 gene (12 exons) was also similar to that of other mammals,

Table 1. Primers and probes used for quantification of the mRNA levels of fatty acid desaturase 3 (FADS3) and stearoyl-CoA desaturase 1 (SCD1) genes by real-time reverse-transcription PCR

\begin{tabular}{llll}
\hline Gene & Forward primer $5^{\prime}-3^{\prime}$ & Reverse primer $5^{\prime}-3^{\prime}$ & 5'-FAM/TAMRA-3' probe \\
\hline Bovine $S C D 1$ & TTGTCCACTTTCTCCTGCTG & GTAGCCATCACTGCCTCTGA & TGGACAGGCAAGCCTCTTCTGTG \\
Bovine $F A D S 3$ & GAAAATCTGGCCTACATGCTGG & GGCGTAGAAGCTGGCGG & TGCATGCAGTGGACGGACTTGCTC \\
Goat $F A D S 1$ & CCGCCTCCCTCTGCAAG & GGCATTGCCCCCAAGCT & AGGGTTATGGCACCAAGGCAGACGG \\
Goat $F A D S 2$ & GCACGGACAAGTGGCTGG & TGCCGGCTGGACCGTT & No probe (Sybr Green) \\
Goat $F A D S 3$ & GAAAATCTGGCCTACATGCTGG & GGCGTAGAAGCTGGCGG & TGCATGCAGTGGACGGACTTGCTC \\
Goat $S C D 1$ & TTTCTTCTCTCACGTGGGTTGG & AGCGTAGCACCCTTTTCTCTGGA & TGCGCAAACACCCAGCT \\
\hline
\end{tabular}


although the first 2 exons are lacking in the goat draft genome sequence of the latest assembly (NC_022321.1). Concerning the FADS3 nucleotide sequence and predicted AA sequence (Figure 2), the alignment of goat (XM_013975910.1), sheep (XM_012146315.1), cattle (NM_001083691.2), human (NM_021727.4), and rat (NM_173137.1) sequences exhibited a very high degree of identity $(>85 \%)$.

\section{Identification and Quantification of the Suspected Trans-11, Cis-13 CLA in Cow Milk}

We have previously used GC-MS analysis of FAME and DMOX derivatives to accurately discriminate the suspected trans-11,cis-13 CLA produced by recombinant rat FADS3 (Rioux et al., 2013) from other CLA isomers and more specifically from the commercially available cis-11,trans-13, cis-11,cis-13, and trans-11,trans-13 CLA isomers. To conclusively identify and quantify the presence of the trans-11,cis-13 CLA isomer in ruminant milk, we analyzed the FAME profile from the European certified reference material anhydrous milk fat (BCR164 obtained from Sigma), which corresponds to a pooled sample of cow milks. Figure $3 \mathrm{~A}$ shows that rumenic acid (cis-9,trans-11 CLA), probably co-eluting with trans-7,cis-9 CLA and trans-8,cis-10 CLA in our experimental conditions $\left(\mathrm{R}_{\mathrm{t}} 27.5 \mathrm{~min}, \mathrm{~m} / z 294 \mathrm{amu}\right)$, represented $1.1 \pm 0.2 \%$ of total FA in this sample. A well-isolated small peak $(0.06 \pm 0.01 \%$ of total FA) with a molecular FAME ion at $m / z 294 \mathrm{amu}$ and with the exact same retention time $\left(\mathrm{R}_{\mathrm{t}} 28.2 \mathrm{~min}\right)$ as the highly probable trans-11,cis-13 CLA produced by recombinant rat FADS3 when incubated with VA (Rioux et al., 2013), was also detected in this sample (Figure $3 \mathrm{~A})$.

This peak was also compared with commercially available standards of $\Delta 11,13$ CLA (cis,trans, cis, cis, and trans,trans but not the trans, cis; Figure 3A). By comparing the GC retention time of the desaturated product of VA by FADS3 with cow milk fat and these standard (Figure 3A), we first excluded the cis, cis $(+0.6$ min) and trans,trans $(+0.9 \mathrm{~min})$ isomers with retention times significantly higher than the unknown $\Delta 11,13$ CLA, whereas the cis,trans isomer had a slightly lower retention time $(-0.2 \mathrm{~min})$. This result suggested that the cis,trans isomer could also be discarded. Therefore, the GC retention times offer several arguments to reasonably conclude that this FA is the trans-11,cis-13 CLA isomer.

In addition, after conversion to DMOX derivatives, the mass spectrum of this CLA present in cow milk fat (Figure 3B) showed a pattern completely similar to the suspected trans-11,cis-13 CLA already characterized in cells expressing rat FADS3 and incubated with VA (Rioux et al., 2013). Indeed, in addition to the DMOX characteristic intense ions at $m / z 113$ and 126 amu and molecular ion at $m / z 333 \mathrm{amu}$, a gap of $12 \mathrm{amu}$ was detected between ions containing 10 and 11 carbons (224 and $236 \mathrm{amu}$ ) and between ions containing 12 and 13 carbons (250 and $262 \mathrm{amu}$ ), showing that this FA is indeed a $\Delta 11,13$ CLA (Figure 3B). More specifically, the ion at $m / z 250$ amu of this DMOX derivative was significantly less abundant than the ion at $m / z 262 \mathrm{amu}$ (Figure 3B), which has already been used to specifically differentiate the suspected trans-11,cis-13 CLA from the commercial cis-11,trans-13 CLA isomer (Figure $3 \mathrm{C}$ ) with the nearest $\mathrm{R}_{\mathrm{t}}$ of $28.0 \mathrm{~min}$ (Figure 3A; Sehat et al., 1998, 1999; Rioux et al., 2013). Therefore, these additional results strongly suggest that this milk FA is the trans-11,cis-13 CLA, representing $0.06 \%$ of total FA in this sample.

\section{Expression of FADS3 mRNA and Synthesis of Suspected Trans-11,Cis-13 CLA}

To investigate the potential synthesis of the suspected trans-11,cis-13 CLA by the FADS3-catalyzed $\Delta 13$-desaturation of VA in ruminant mammary tissue, we first quantified the relative mRNA expression of FADS3 and SCD1 in bovine mammary MAC-T and BME-UV epithelial cells. Figures $4 \mathrm{~A}$ and $4 \mathrm{~B}$ show that $F A D S 3$ and $S C D 1$ mRNA were expressed in these 2 bovine mammary cell models, FADS3 mRNA being surprisingly 10 times more abundant than $S C D 1$ mRNA. When incubated with $200 \mu M$ VA, FADS3 mRNA levels were not modified, whereas $S C D 1 \mathrm{mRNA}$ levels decreased, although not significantly (Figures $4 \mathrm{~A}$ and 4B). This observation is consistent with the described SCD1 gene expression modulation through the associate gene regulatory protein SREBP-1 downregulation (Keating et al., 2006; Minville-Walz et al., 2012; Jacobs et al., 2013).

The MAC-T and BME-UV mammary epithelial cells were then incubated for $24 \mathrm{~h}$ with media supplemented with VA or $\left[1-{ }^{13} \mathrm{C}\right]-\mathrm{VA}$, and a control medium without FA. Rumenic acid produced by $\Delta 9$-desaturation of VA was easily detected $(1.88 \pm 0.44 \%$ of FA in BME-UV cells and $2.22 \pm 1.05 \%$ of FA in MAC- $\mathrm{T}$ cells, $\mathrm{n}=$ 3) after incubation with VA (Figures $4 \mathrm{~B}$ and 4D). A smaller peak $(0.49 \pm 0.24 \%$ of FA in BME-UV cells and $0.82 \pm 0.25 \%$ of FA in MAC-T cells, $\mathrm{n}=3$ ) with $\mathrm{R}_{\mathrm{t}} 28.2 \mathrm{~min}$ and FAME molecular ion at $\mathrm{m} / z 294 \mathrm{amu}$ (incubation with ${ }^{12} \mathrm{C}-\mathrm{VA}$ ) or $\mathrm{m} / z 295 \mathrm{amu}$ (incubation with ${ }^{13} \mathrm{C}-\mathrm{VA}$ ), similar to the suspected trans-11, cis-13 CLA previously characterized in milk fat sample (Figure 3A), was also specifically detected (Figures 4C 
Capra

Ovis

Bos

Homo

Rattus

Consensus

Capra

Ovis

Bos

Homo

Rattus

Consensus

Capra

Ovis

Bos

Homo

Rattus

Consensus

Capra

Ovis

Bos

Homo

Rattus

Consensus

Capra

ovis

Bos

Homo

Rattus

Consensus

Capra

Ovis

Bos

Homo

Rattus

Consensus

Capra

Ovis

Bos

Homo

Rattus

Consensus

Capra

Ovis

Bos

Homo

Rattus

Consensus

Capra

Ovis

Bos

Homo

Rattus

Consensus

MGGVGEPD. . ....WEPAQR GAPLPTLRWE QVRRHNLPGD KWLVIERRVY MGGVGEPD ......WEPAOR GAPLPTLRWE OVRRHNLPGD KWLVIERRVY MGGVGEPD. . ....WEPGQR GAPLPTLRWE QVRRHNLPGD KWLVIERRVY MGGVGEPG. . . PREGPAQP GAPLPTECWE QIRAHDQPGD KWLVIERRVY MGGVGEPGGG PGPREGPAPI GAPLPIERWE OIROHDLPGD KWLVIERRVY MGGVGEPg... ..pregPaq. GAPLPtfrWE Q!R.H\#IPGD KWLVIERRVY

51

100

DISRWAQRHP GGSRLIGHHG AEDATDAFHA FHQDLSFVRK FLQPLLIGEI DISRWAORHP GGSRLIGHHG AEDATDAFHA FHODLSFVRK FLOPLLIGEL DISRWAQRHP GGSRLIGHHG AEDATDAFHA FHQDLSFVRK FLQPLLIGEI DISRWAQRHP GGSRLIGHHG AEDATDAFRA FHQDLNFVRK FLQPLLIGEL DISRWAQRHP GGSRLIGHHS AEDATDAFHA FHQDLHFVRK FLKPLLIGEI DISRWAQRHP GGSRLIGHHg AEDATDAFhA FHQDL.FVRK FLqPLLIGEI

101

150

APEEPSQDGP QNTQLIEDFR ALRQAVEDMK LFEAKPAFFG LLLGHILAMF APEEPSQDGP QNTQLIEDFR ALRQAVEDMK LFEAKPAFEG LLLGHILAME APEEPSODGP ONTOLIEDFR ALROAVEDMK LFEAKPAFFG LLLGHILAME APEEPSQDGP LNAQLVEDFR ALHQAAEDMK LFDASPTFFA FLLGHILAME APEEPSQDGA QNAQLIEDFR ALRQAAEDMK LFEADTTFFA LLLGHILAMF APEEPSQDGp qNaQL!EDFR ALrQAaEDMK LF\#A.ptFFa ILLGHILAMF

151

VLAWLMIYLI GPGWLPSILA ALILAVSQAQ SWCLQHDLGH TSIFRNSRWN VLAWLMIYLL GPGWLPSTLA ALILAVSQAQ SWCLQHDLGH TSIFRNSRWN VLAWLMIYML GPGWVPSTLA ALILAISOAO SWCLOHDLGH TSIFRNSRWN VLAWLLIYLI GPGWVPSALA AFILAISQAQ SWCLQHDLGH ASIFKKSWWN LLAWLLVYLL GPGWVSSVLA ALILAISQAQ CWCLQHDLGH ASIFPKSRWN VLAWLS!YSL GPGWVPS. LA AIILA!SQAQ sWCLQHDLGH aSIE.kSrWN

201 250

HLAQQFVMGQ LKGESAHWWN FRHFQHHAKP NIFHKDPDVT VAPVELLGES HLAQQFVMGQ LKGFSAHWWN FRHFQHHAKP NIFHKDPDVT VAPVELLGES HLAQQFVMGQ LKGFSAHWWN FRHFQHHAKP NIFHKDPDVT VAPVELLGES HVAOKFVMGQ LKGFSAHWWN FRHFOHHAKP NIFHKDPDVT VAPVELLGES HVAQQFVMGQ LKGFSAHWWN FRHFQHHAKP NIFHKDPDVT VAPVFLLGES HVAQqFVMGQ LKGFSAHWWN FRHFQHHAKP NIFHKDPDVT VAPVFLLGES

251

300

SIEYGKKKRR YLPYNHOHLY FFLIGPPLLT LVNFEVENLA YMLVCMOWTD SIEYGKKKRR YLPYNHQHLY FELIGPPLLT LVNFEVENLA YMLVCMQWTD SVEYGKKKRR YLPYNHQHLY FELIGPPLLT LVNFEVENLA YMLVCMQWMD SVEYGKKKRR YLPYNQQHLY FELIGPPLLT LVNFEVENLA YMLVCMQWAD SVEYGKKKRR YLPYNHQHLY FELIGPPLLT LVNFEVENLA YMLVCMQWTD S!EYGKKKRR YLPYNhQHLY FFLIGPPLLT LVNFEVENLA YMLVCMQWtD

301

350

LLWAASFYAR ELLSYVPFYG IPGALLLFVA VRVLESHWFV WITOMNHIPR LLWAASFYAR FLLSYVPEYG IPGALLLFVA VRVLESHWFV WITOMNHIPR LLWAASFYAR FLLSYIPEYG IPGALLLFVA VRVLESHWEV WITQMNHIPR LLWAASFYAR FFLSYLPFYG VPGVLLFFVA VRVLESHWFV WITOMNHIPK LLWAASFYSR FFLSYSPEYG ATGTLLLFVA VRVLESHWEV WITQMNHIPK LLWAASFYaR FfLSY.PFYG .PG.LLIFVA VRVLESHWEV WITQMNHIPK

351

400

EIGHEKHRDW ASSQLAATCN VEPSLFIDWE SGHLNEQIEH HLFPTMPRHN EIGHEKHRDW ASSQLAATCN VEPSLFIDWF SGHLNEQIEH HLFPTMPRHN EIGHEKHRDW ASSQLAATCN VEPSLFIDWF SGHLNEQIEH HLFPTMPRHN EIGHEKHRDW VSSQLAATCN VEPSLETNWE SGHLNFQIEH HLFPRMPRHN EIGHEKHRDW ASSQLAATCN VEPSLFIDWE SGHLNEQIEH HLFPTMPRHN EIGHEKHRDW ASSQLAATCN VEPSLFI\#WE SGHLNEQIEH HLFPTMPRHN

401

449

YRRVAPLVKA LCAKHGLSYE VKPFLTALVD IVRSLKKSGN VWLEAYLHQ YRRVAPLVKA LCAKHGLSYE VKPFLTALVD IVRSLKKSGN VWLEAYLHQ YRRVAPLVKA LCAKHGLSYE VKPELTALVD IIRSLKKSGN VWLEAYLHQ YSRVAPLVKS LCAKHGLSYE VKPFLTALVD IVRSLKKSGD IWLDAYLHQ YRRVAPLVKA ECAKHGLHYE VKPFLTALVD IIGSLKKSGD IWLDAYLHQ YrRVAPLVKa ICAKHGLSYE VKPFLTALVD I!rSLKKSG\# !WL\#AYLHO

Figure 2. Alignment of the AA sequences of goat, sheep, cow, rat, and human fatty acid desaturase 3 (FADS3) deduced from their available nucleotide sequences. The alignment of goat (Capra, XM_013975910.1), sheep (Ovis, XM_012146315.1), cattle (Bos, NM_001083691.2), human (Homo, NM_021727.4), and rat (Rattus NM_173137.1) sequences exhibited a very high degree of identity (>85\%) (http://multalin.toulouse. inra.fr/multalin/). 

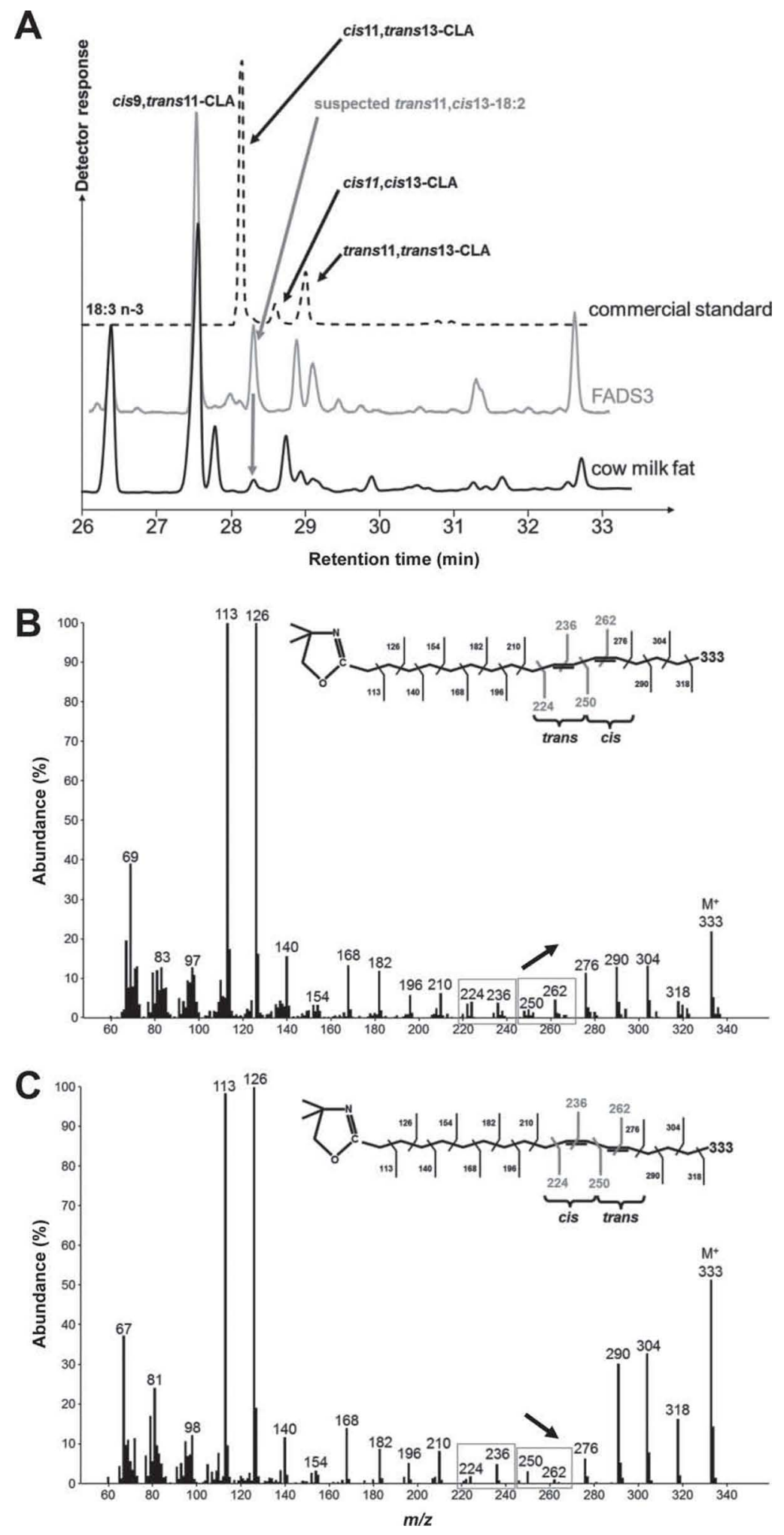

Figure 3. Identification and quantification of the suspected trans-11, cis-13 CLA in cow milk standard sample. (A) The GC-MS profile of the European certified reference material anhydrous milk fat (BCR164) compared with FAME extracted from COS-7 cells (African green monkey fibroblasts) expressing recombinant rat fatty acid desaturase 3 (FADS3) and incubated with vaccenic acid and a commercial mixture of cis-11,trans-13; cis-11,cis-13; and trans-11,trans-13 CLA as FAME standards. (B) Electron-impact mass spectrum of the 4,4-dimethyloxazoline (DMOX) derivative of the suspected trans-11,cis-13 CLA from the European certified reference material anhydrous milk fat (BCR164). (C) Electron-impact mass spectrum of the DMOX derivative of the commercial cis-11,trans-13 CLA. 

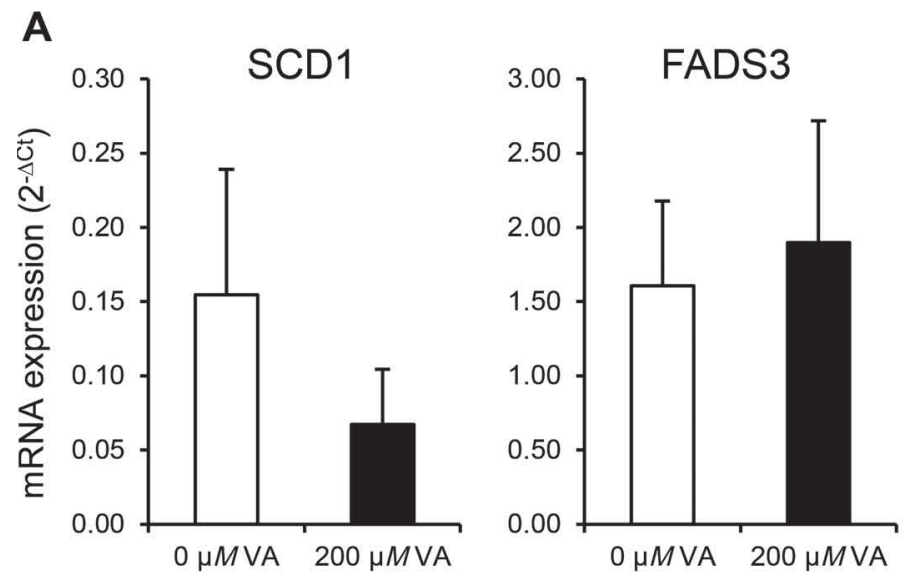

C
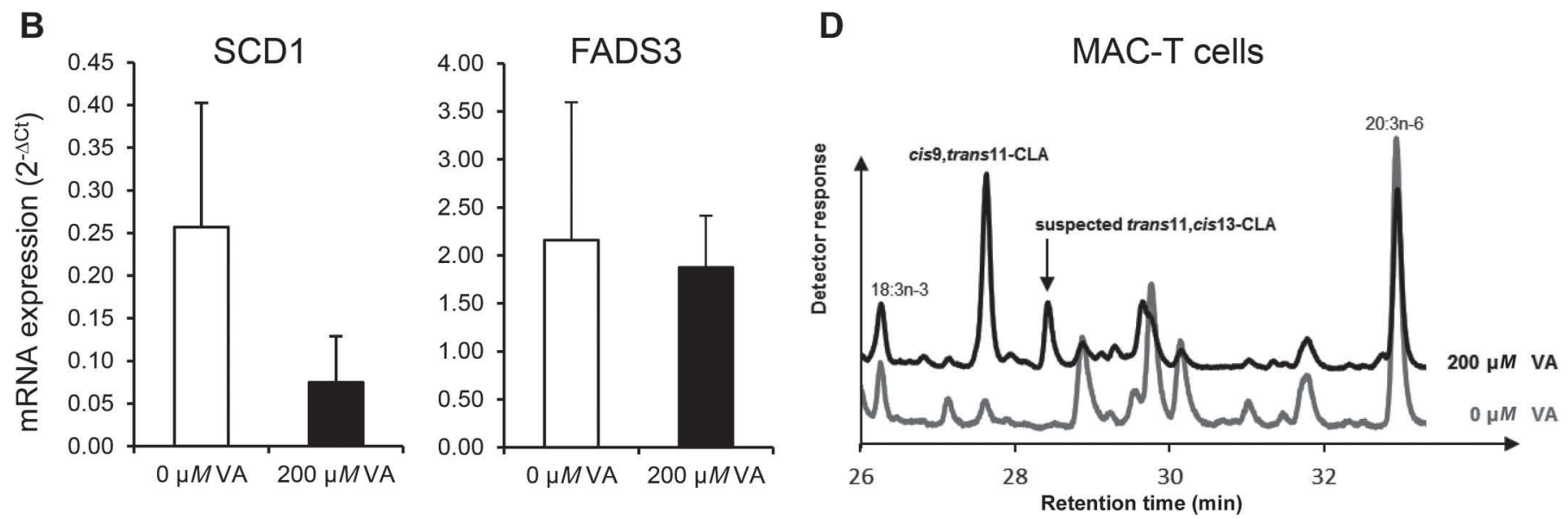

Figure 4. Characterization of bovine BME-UV and MAC-T mammary epithelial cells incubated with vaccenic acid (VA). Cells were incubated for $24 \mathrm{~h}$ with albumin-bound VA $(200 \mu M)$ or with no fatty acids (FA; $0 \mu M$ VA). The stearoyl-CoA desaturase 1 (SCD1) and fatty acid desaturase 3 (FADS3) mRNA levels were quantified in BME-UV (A) and MAC-T (B) cells. Data are presented as means \pm SEM $(\mathrm{n}=3)$. The FAME extracted from bovine BME-UV (C) and MAC-T (D) cells were identified and quantified by GC-MS. The identity of each important FA is indicated above its respective peak. Panels $\mathrm{C}$ and $\mathrm{D}$ are representative examples of $\mathrm{n}=3$ distinct experiments.

and 4D). Indeed, when incubated mammary epithelial cells were incubated with cis-9-18:1, cis-11-18:1 or cis9,trans-11-18:2, this specific FA was not detected (data not shown).

To clearly identify this CLA isomer obtained from incubation of VA with bovine mammary epithelial cells, it was converted both to MTAD adduct and DMOX derivative (Figure 5), followed by GC-MS analysis. The mass spectrum of the MTAD adduct (Figure 5A) of the suspected trans-11,cis-13 CLA contained a molecular ion at $m / z 407$ amu and 3 very characteristic ions at $m / z 350,318$, and $222 \mathrm{amu}$, identifying this CLA as a $\Delta 11,13$ isomer, whereas rumenic acid MTAD adduct (Figure 5B) showed a similar molecular ion at $\mathrm{m} / z 407$ amu but 3 other characteristic ions at $m / z 322,290$, and $250 \mathrm{amu}$ (Berdeaux et al., 1997). Figure 5C shows again that the DMOX mass spectrum of the suspected trans-11,cis-13 CLA was characterized by 2 gaps between ions containing 10 and 11 carbons (224 and 236 $\mathrm{amu}$ ) and between ions containing 12 and 13 carbons (250 and $262 \mathrm{amu}$ ), locating the double bonds. More specifically, its ion at $m / z 250 \mathrm{amu}$ was less abundant than its ion at $m / z 262 \mathrm{amu}$, as already shown in milk fat sample (Figure 3B). Again, these results offer several arguments to reasonably conclude that this FA is the trans-11,cis-13 CLA isomer.

To conclude, incubation of mammary epithelial cells with VA resulted in a $\Delta 9$-desaturation index [assessed as $\mathrm{RA} /(\mathrm{VA}+\mathrm{RA}+$ trans-11,cis-13 CLA)] of 4.4 and $5.7 \%$, and a $\Delta 13$-desaturation index [assessed as trans11,cis-13 CLA/(VA+RA+trans-11,cis-13 CLA)] of 1.1 and $2 \%$ in BME-UV and MAC-T cells, respectively. 


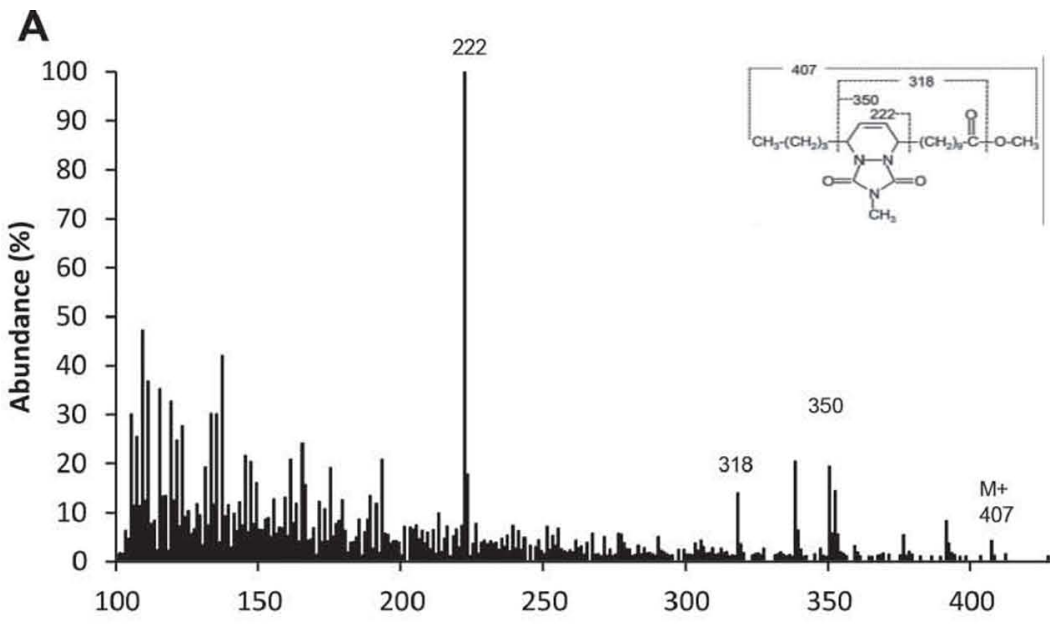

B
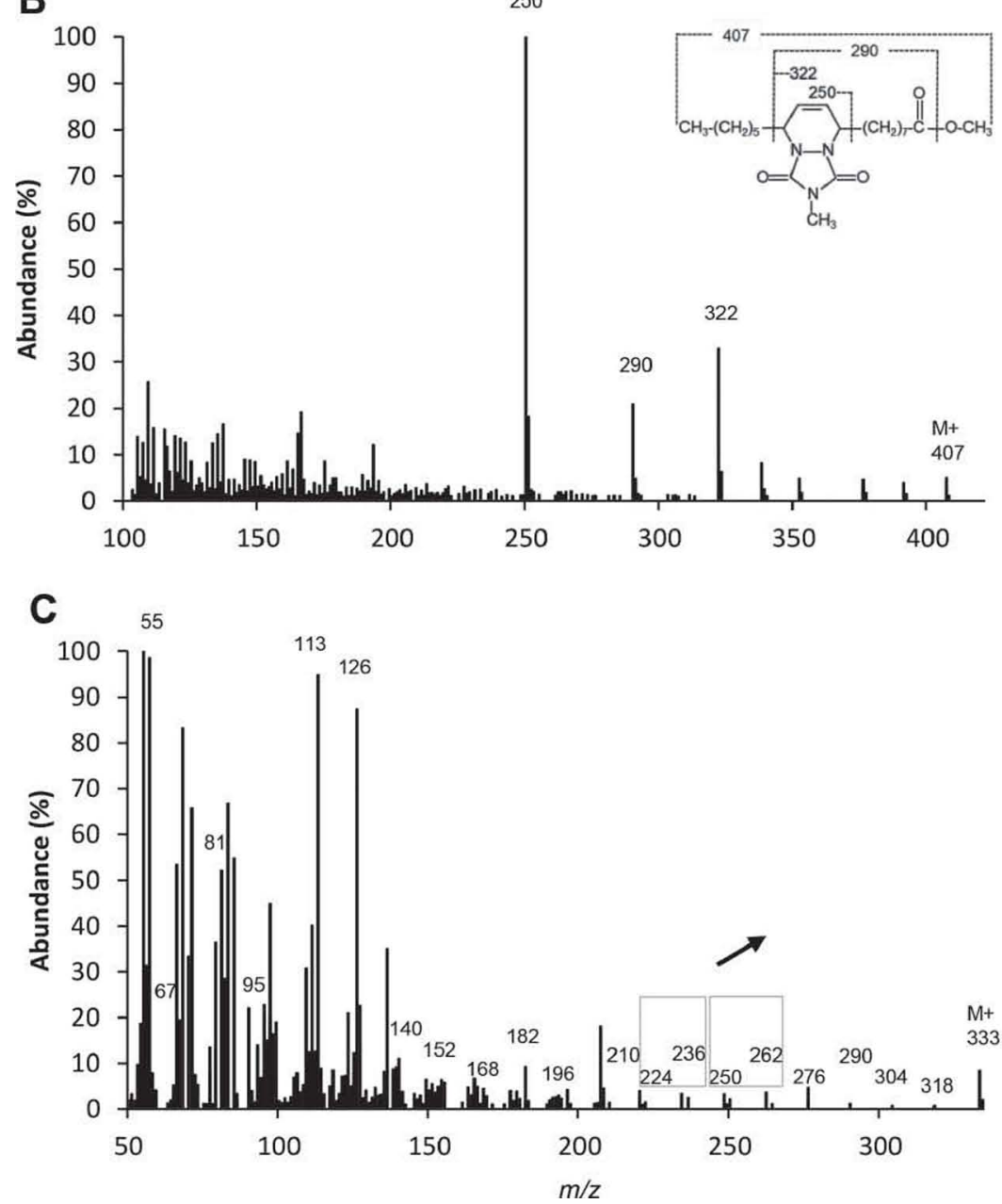

Figure 5. Structural characterization of the CLA obtained after incubation of vaccenic acid (VA) with BME-UV epithelial cells. Electronimpact mass spectrum of the 4-methyl-1,2,4-triazoline-3,5-dione (MTAD) adduct of the suspected trans-11,cis-13 CLA (A) contains a molecular ion at $m / z 407$ atomic mass units (amu) and 3 very characteristic ions at $m / z 350,318$, and 222 amu, identifying this CLA as a $\Delta 11,13$ isomer. Electron-impact mass spectrum of the MTAD adduct of cis-9,trans-11 CLA (B) also shows a similar molecular ion at $m / z 407$ amu but 3 other characteristic ions at $m / z 322,290$, and 250 amu. The 4,4-dimethyloxazoline mass spectrum of the suspected trans-11,cis-13 CLA (C) was characterized by 2 gaps (boxed areas) between ions containing 10 and 11 carbons (224 and $236 \mathrm{amu}$ ) and between ions containing 12 and 13 carbons (250 and $262 \mathrm{amu}$ ), locating the double bonds in position 11-12 and 13-14. Specifically, its ion at $m / z 250$ amu was less abundant than its ion at $m / z 262 \mathrm{amu}$, as indicated by the arrow, and as shown in the milk fat sample (Figure 3B), which strongly suggests that this fatty acid is the trans-11,cis-13 CLA isomer. 

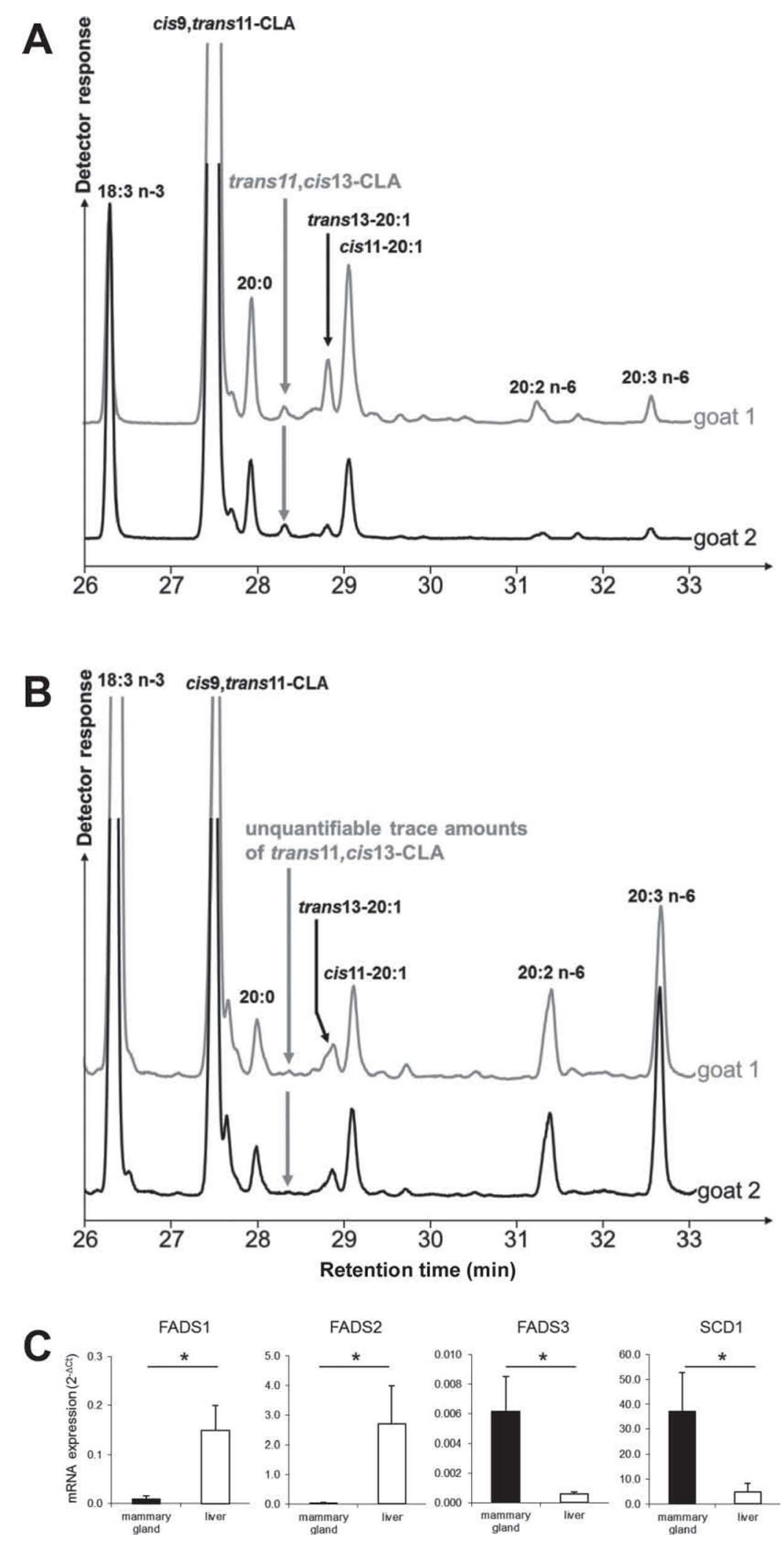

Figure 6. Identification of the suspected trans-11,cis-13 CLA and quantification of fatty acid desaturase 3 (FADS3) mRNA in goat mammary tissue. (A) The GC-MS profile of fatty acids extracted from goat mammary tissue (2 representative examples). (B) GC-MS profile of fatty acids extracted from goat liver (2 representative examples). (C) Comparison of FADS1, FADS2, FADS3, and SCD1 mRNA levels in goat mammary tissue and liver $(\mathrm{n}=8)$. 

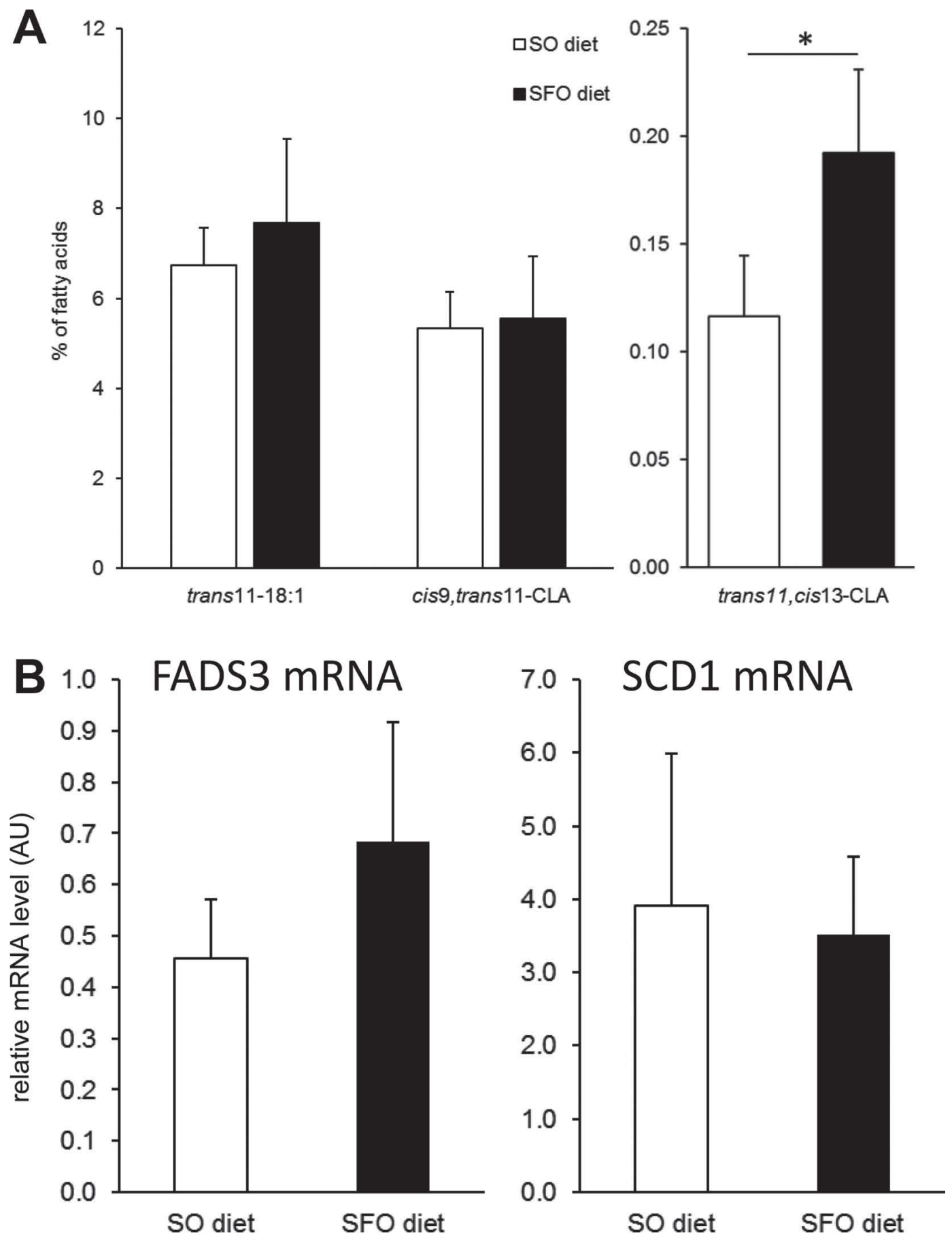

Figure 7. Effect of sunflower-seed oil (SO) and sunflower-seed oil and fish oil (2:1) plus starch from rolled barley (SFO) diets containing exactly the same level of dietary 18:3n-3 on the amount of trans-11-18:1, cis-9, trans-11 CLA and suspected trans-11, cis-13 CLA and the levels of fatty acid desaturase 3 (FADS3) and SCD1 mRNA in goat mammary tissue. (A) Quantification (\% of FA) of trans-11-18:1, cis-9, trans-11 CLA, and suspected trans-11,cis-13 CLA after GC-MS analysis of FAME extracted from goat mammary tissue. (B) Relative expression of FADS3 and $S C D 1$ mRNA levels in goat mammary tissue. Data are presented as means $\pm \mathrm{SD}(\mathrm{n}=4)$. 


\section{FADS3 mRNA and Suspected Trans-11,Cis-13 CLA Concomitant Presence in Goat Mammary Tissue and Absence in Goat Liver}

To analyze the potential concomitant presence of FADS3 mRNA and of the suspected trans-11,cis-13 CLA in vivo in another ruminant model, we took advantage of tissue samples collected from a study carried out with lactating goats, which has already been published (Bernard et al., 2010; Toral et al., 2013). We re-analyzed the mammary tissue and liver FA compositions, paying particular attention to the suspected trans-11,cis-13 CLA and additionally quantified FADS3 mRNA. Figure $6 \mathrm{~A}$ shows that the suspected trans-11,cis-13 CLA ( $\left.\mathrm{R}_{\mathrm{t}} 28.2 \mathrm{~min}\right)$ was detected in goat mammary tissue, representing $0.15 \pm 0.05 \%$ of total FA $(\mathrm{n}=8)$, whereas its trace amounts were not quantifiable in the liver (Figure 6B). Figure 6C additionally shows that FADS3 and SCD1 mRNA levels were significantly higher in the mammary secretory tissue than in the liver of goats. Therefore, the higher presence of the suspected trans-11,cis-13 CLA in goat mammary tissue is consistent with FADS3 mRNA being expressed in this tissue, compared with very low levels of both suspected trans-11,cis-13 CLA and FADS3 mRNA in goat liver. However, in contrast to the results obtained with MAC$\mathrm{T}$ and BME-UV epithelial cells (Figure 4A and 4B), FADS3 mRNA was about 5,000 times less abundant than $S C D 1$ mRNA in goat mammary tissue (Figure $6 \mathrm{C}$ ). This result suggested first that FADS3 may be less expressed in goats than in cows. Of course, FADS3 mRNA levels may also be different in mammary tissue samples collected in vivo and in mammary cultured cells. As previously shown (Toral et al., 2013), FADS1 and FADS2 mRNA levels were conversely significantly higher in the liver than in the mammary tissue (Figure $6 \mathrm{C})$.

In a second approach to get further information regarding the effect of dietary PUFA on the amount of the suspected trans-11,cis-13 CLA and FADS3 mRNA in goat mammary tissue, we took into consideration that the goats were fed during $21 \mathrm{~d}$ with 2 experimental diets containing exactly the same amounts of $18: 3 n-$ 3 but different amounts of other PUFA (Toral et al., $2013)$. Half of the goats $(\mathrm{n}=4)$ were fed $90 \mathrm{~g}$ of sunflower oil per day (sunflower oil diet including $27.3 \mathrm{~g} /$ $\mathrm{kg}$ of DM of $18: 2 \mathrm{n}-6$ and $6.2 \mathrm{~g} / \mathrm{kg}$ of $18: 3 \mathrm{n}-3)$. Another group of $\mathrm{n}=4$ goats was fed with a combination of 60 $\mathrm{g}$ of sunflower oil and $30 \mathrm{~g}$ of fish oil (sunflower and fish oil diet including $21.6 \mathrm{~g} / \mathrm{kg}$ of DM of $18: 2 \mathrm{n}-6,1.4$ $\mathrm{g} / \mathrm{kg}$ of $20: 5 \mathrm{n}-3,1.0 \mathrm{~g} / \mathrm{kg}$ of $22: 6 \mathrm{n}-3$ and again $6.2 \mathrm{~g} /$ $\mathrm{kg}$ of 18:3n-3) plus $59 \mathrm{~g} / \mathrm{kg}$ of DM of starch from rolled barley. Considering now the effect of the 2 diets, Figure $7 \mathrm{~A}$ shows that the suspected trans-11,cis-13 CLA was significantly higher $(0.19 \pm 0.04 \%$ vs. $0.12 \pm 0.03 \%)$ in the mammary tissue of goats fed the sunflower and fish oil diet compared with goats fed the sunflower oil diet. In addition, a trend toward the increase of FADS3 mRNA was observed (Figure 7B), even if the difference was not statistically significant $(P=0.13)$ due to the low number of animals. Conversely, no effect of the diets has already been shown on trans-11-18:1, cis9,trans-11 CLA (Figure 7A), and on SCD1 mRNA level (Toral et al., 2013), as also re-analyzed in the present study (Figure 7B). Because the 2 diets contained the same amounts of 18:3n-3, we can therefore hypothesize that its ruminal biohydrogenation potentially leading to trans-11,cis-13 CLA production may have been similar and can speculate that mammary tissue FADS3 would therefore have been involved in the elevated trans-11,cis-13 CLA level. Interestingly, the expression of the FADS3 transcript was also upregulated by dietary long-chain PUFA in baboon liver, whereas other desaturase (FADS1 and FADS2) mRNA levels were downregulated (Reardon et al., 2013). These results are also in agreement with the positive correlation between trans-11,cis-13 CLA and trans-11-18:1 levels described in milk (Lerch et al., 2012).

\section{CONCLUSIONS}

A vaccenate $\Delta 13$-desaturase activity has recently been attributed to the FADS3 enzyme in rodents (Rioux et al., 2013). We hypothesized in the present study that this activity would be common to all mammals, explaining at least partly the presence of the trans11,cis-13 CLA in ruminant milk. Indeed, this study provides several lines of evidence that, by analogy with rumenic acid, the trans-11,cis-13 CLA may originate both from ruminal biohydrogenation and from direct FADS3-catalyzed $\Delta 13$-desaturation of VA in mammary tissue.

\section{ACKNOWLEDGMENTS}

The authors thank Frédéric Dessauge (UMR Pegase, INRA Saint-Gilles, France) for the MAC-T and BMEUV cell lines. The authors also gratefully acknowledge O. Loreau (CEA, Saclay and Cadarache, France) for the supply of $\left[1-{ }^{13} \mathrm{C}\right]$-vaccenic acid and the Transqual project (Clermont-Ferrand, France; ANR-05-PNRANo.5.E.24). This work was supported by the Groupe Lipides et Nutrition (GLN, Paris, France).

\section{REFERENCES}

Berdeaux, O., W. W. Christie, F. D. Gunstone, and J.-L. Sebedio. 1997. Large-scale synthesis of methyl cis-9, trans-11-octadecadi- 
enoate from methyl ricinoleate. J. Am. Oil Chem. Soc. 74:10111015. https://doi.org/10.1007/s11746-997-0018-z.

Bernard, L., J. Mouriot, J. Rouel, F. Glasser, P. Capitan, E. PujosGuillot, J. M. Chardigny, and Y. Chilliard. 2010. Effects of fish oil and starch added to a diet containing sunflower-seed oil on dairy goat performance, milk fatty acid composition and in vivo delta9desaturation of $[13 \mathrm{C}]$ vaccenic acid. Br. J. Nutr. 104:346-354.

Christie, W. W., G. Dobson, and R. O. Adlof. 2007. A practical guide to the isolation, analysis and identification of conjugated linoleic acid. Lipids 42:1073-1084.

Corl, B. A., L. H. Baumgard, J. M. Griinari, P. Delmonte, K. M. Morehouse, M. P. Yurawecz, and D. E. Bauman. 2002. Trans7,cis-9 CLA is synthesized endogenously by delta9-desaturase in dairy cows. Lipids 37:681-688.

De la Fuente, M. A., P. Luna, and M. Juarez. 2006. Chromatographic techniques to determine conjugated linoleic acid idomers. Trends Analyt. Chem. 25:917-926.

Dobson, G. 1998. Identification of conjugated fatty acids by gas chromatography-mass spectrometry of 4-methyl-1,2,4-triazoline-3,5dione adducts. J. Am. Oil Chem. Soc. 75:137-142. https://doi. org/10.1007/s11746-998-0024-9.

Dugan, M. E., J. K. Kramer, W. M. Robertson, W. J. Meadus, N. Aldai, and D. C. Rolland. 2007. Comparing subcutaneous adipose tissue in beef and muskox with emphasis on trans 18:1 and conjugated linoleic acids. Lipids 42:509-518.

Fukuda, S., Y. Nakanishi, E. Chikayama, H. Ohno, T. Hino, and J. Kikuchi. 2009. Evaluation and characterization of bacterial metabolic dynamics with a novel profiling technique, real-time metabolotyping. PLoS One 4:e4893. https://doi.org/10.1371/journal. pone.0004893.

Griinari, J. M., B. A. Corl, S. H. Lacy, P. Y. Chouinard, K. V. Nurmela, and D. E. Bauman. 2000. Conjugated linoleic acid is synthesized endogenously in lactating dairy cows by Delta(9)-desaturase. J. Nutr. 130:2285-2291.

Guillou, H., V. Rioux, D. Catheline, J. N. Thibault, M. Bouriel, S. Jan, S. D'Andrea, and P. Legrand. 2003. Conversion of hexadecanoic acid to hexadecenoic acid by rat Delta 6-desaturase. J. Lipid Res. 44:450-454.

Harfoot, C. G., and G. P. Hazlewood. 1997. Lipid metabolism in the rumen. Pages 382-426 in The Rumen Microbial Ecosystem. P. N. Hobson and C. S. Stewart, ed. Springer Netherlands, Dordrecht, the Netherlands.

Jacobs, A. A. A., J. Dijkstra, J. S. Liesman, M. J. VandeHaar, A. L. Lock, A. M. van Vuuren, W. H. Hendriks, and J. van Baal. 2013. Effects of short- and long-chain fatty acids on the expression of stearoyl-CoA desaturase and other lipogenic genes in bovine mammary epithelial cells. Animal 7:1508-1516.

Jenkins, T. C., R. J. Wallace, P. J. Moate, and E. E. Mosley. 2008. Board-invited review: Recent advances in biohydrogenation of unsaturated fatty acids within the rumen microbial ecosystem. J. Anim. Sci. 86:397-412.

Keating, A. F., J. J. Kennelly, and F. Q. Zhao. 2006. Characterization and regulation of the bovine stearoyl-CoA desaturase gene promoter. Biochem. Biophys. Res. Commun. 344:233-240.

Kraft, J., M. Collomb, P. Mockel, R. Sieber, and G. Jahreis. 2003. Differences in CLA isomer distribution of cow's milk lipids. Lipids 38:657-664.

Lerch, S., K. J. Shingfield, A. Ferlay, A. Vanhatalo, and Y. Chilliard. 2012. Rapeseed or linseed in grass-based diets: effects on conjugated linoleic and conjugated linolenic acid isomers in milk fat from Holstein cows over 2 consecutive lactations. J. Dairy Sci. 95:7269-7287.

Lock, A. L., and D. E. Bauman. 2004. Modifying milk fat composition of dairy cows to enhance fatty acids beneficial to human health. Lipids 39:1197-1206.

Loreau, O., A. Maret, D. Poullain, J. M. Chardigny, J. L. Sebedio, B. Beaufrere, and J. P. Noel. 2000. Large-scale preparation of (9Z,12E)-[1-(13)C]-octadeca-9,12-dienoic acid, (9Z,12Z,15E)-[1-(13)C]-octadeca-9,12,15-trienoic acid and their [1-(13)C] all-cis isomers. Chem. Phys. Lipids 106:65-78.
Luna, P., M. A. de la Fuente, and M. Juarez. 2005. Conjugated linoleic acid in processed cheeses during the manufacturing stages. J. Agric. Food Chem. 53:2690-2695.

Marquardt, A., H. Stohr, K. White, and B. H. Weber. 2000. cDNA cloning, genomic structure, and chromosomal localization of three members of the human fatty acid desaturase family. Genomics $66: 175-183$.

Minville-Walz, M., J. Gresti, L. Pichon, S. Bellenger, J. Bellenger, M. Narce, and M. Rialland. 2012. Distinct regulation of stearoyl-CoA desaturase 1 gene expression by cis and trans C18:1 fatty acids in human aortic smooth muscle cells. Genes Nutr. 7:209-216.

Nakamura, M. T., and T. Y. Nara. 2004. Structure, function, and dietary regulation of delta6, delta5, and delta9 desaturases. Annu. Rev. Nutr. 24:345-376.

Palmquist, D. L., A. L. Lock, K. J. Shingfield, and D. E. Bauman. 2005. Biosynthesis of conjugated linoleic acid in ruminants and humans. Adv. Food Nutr. Res. 50:179-217. https://doi.org/10.1016/ S1043-4526(05)50006-8.

Park, W. J., K. S. Kothapalli, H. T. Reardon, L. Y. Kim, and J. T. Brenna. 2009. Novel fatty acid desaturase 3 (FADS3) transcripts generated by alternative splicing. Gene 446:28-34.

Pedrono, F., H. Blanchard, M. Kloareg, S. D'Andrea, S. Daval, V. Rioux, and P. Legrand. 2010. The fatty acid desaturase 3 gene encodes for different FADS3 protein isoforms in mammalian tissues. J. Lipid Res. 51:472-479.

Petri, R. M., C. Mapiye, M. E. R. Dugan, and T. A. McAllister. 2014. Subcutaneous adipose Fatty Acid profiles and related rumen bacterial populations of steers fed red clover or grass hay diets containing flax or sunflower-seed. PLoS One 9:e104167. https:// doi.org/10.1371/journal.pone.0104167.

Piperova, L. S., J. Sampugna, B. B. Teter, K. F. Kalscheur, M. P. Yurawecz, Y. Ku, K. M. Morehouse, and R. A. Erdman. 2002. Duodenal and milk trans octadecenoic acid and conjugated linoleic acid (CLA) isomers indicate that postabsorptive synthesis is the predominant source of cis-9-containing CLA in lactating dairy cows. J. Nutr. 132:1235-1241.

Ramakers, C., J. M. Ruijter, R. H. Deprez, and A. F. Moorman. 2003. Assumption-free analysis of quantitative real-time polymerase chain reaction (PCR) data. Neurosci. Lett. 339:62-66.

Reardon, H. T., A. T. Hsieh, W. J. Park, K. S. D. Kothapalli, J. C. Anthony, P. W. Nathanielsz, and J. T. Brenna. 2013. Dietary longchain polyunsaturated fatty acids upregulate expression of FADS3 transcripts. Prostaglandins Leukot. Essent. Fatty Acids 88:15-19. https://doi.org/10.1016/j.plefa.2012.02.003.

Rioux, V., B. Choque, H. Ezanno, C. Duby, D. Catheline, and P. Legrand. 2015. Influence of the cis-9, cis- 12 and cis- 15 double bond position in octadecenoic acid (18:1) isomers on the rat FADS2-catalyzed $\Delta 6$-desaturation. Chem. Phys. Lipids 187:10-19. https:// doi.org/10.1016/j.chemphyslip.2015.02.001.

Rioux, V., P. Lemarchal, and P. Legrand. 2000. Myristic acid, unlike palmitic acid, is rapidly metabolized in cultured rat hepatocytes. J. Nutr. Biochem. 11:198-207.

Rioux, V., F. Pedrono, H. Blanchard, C. Duby, N. Boulier-Monthean, L. Bernard, E. Beauchamp, D. Catheline, and P. Legrand. 2013. Trans-vaccenate is Delta13-desaturated by FADS3 in rodents. J. Lipid Res. 54:3438-3452.

Sehat, N., J. K. Kramer, M. M. Mossoba, M. P. Yurawecz, J. A. Roach, K. Eulitz, K. M. Morehouse, and Y. Ku. 1998. Identification of conjugated linoleic acid isomers in cheese by gas chromatography, silver ion high performance liquid chromatography and mass spectral reconstructed ion profiles. Comparison of chromatographic elution sequences. Lipids 33:963-971.

Sehat, N., R. Rickert, M. M. Mossoba, J. K. Kramer, M. P. Yurawecz, J. A. Roach, R. O. Adlof, K. M. Morehouse, J. Fritsche, K. D. Eulitz, H. Steinhart, and Y. Ku. 1999. Improved separation of conjugated fatty acid methyl esters by silver ion-high-performance liquid chromatography. Lipids 34:407-413.

Shen, X., D. Dannenberger, K. Nuernberg, G. Nuernberg, and R. Zhao. 2011. Trans-18:1 and CLA isomers in rumen and duodenal digesta of bulls fed n-3 and n-6 PUFA-based diets. Lipids 46:831-841. 
Shingfield, K. J., S. Ahvenjarvi, V. Toivonen, A. Vanhatalo, P. Huhtanen, and J. M. Griinari. 2008b. Effect of incremental levels of sunflower-seed oil in the diet on ruminal lipid metabolism in lactating cows. Br. J. Nutr. 99:971-983.

Shingfield, K. J., A. Arölä, S. Ahvenjärvi, A. Vanhatalo, V. Toivonen, J. M. Griinari, and P. Huhtanen. 2008a. Ruminal infusions of cobalt-EDTA reduce mammary delta9-desaturase index and alter milk fatty acid composition in lactating cows. J. Nutr. 138:710717.

Taniguchi, M., A. Arakawa, M. Motoyama, I. Nakajima, M. Nii, and S. Mikawa. 2014. Genomic structural analysis of porcine fatty acid desaturase cluster on chromosome 2. Anim. Sci. J. Nihon Chikusan Gakkaiho. https://doi.org/10.1111/asj.12308.
Toral, P. G., L. Bernard, C. Delavaud, D. Gruffat, C. Leroux, and Y. Chilliard. 2013. Effects of fish oil and additional starch on tissue fatty acid profile and lipogenic gene mRNA abundance in lactating goats fed a diet containing sunflower-seed oil. Animal 7:948-956. https://doi.org/10.1017/S1751731113000049.

Toral, P. G., K. J. Shingfield, G. Hervás, V. Toivonen, and P. Frutos. 2010. Effect of fish oil and sunflower oil on rumen fermentation characteristics and fatty acid composition of digesta in ewes fed a high concentrate diet. J. Dairy Sci. 93:4804-4817.

Wahle, K. W. J., S. D. Heys, and D. Rotondo. 2004. Conjugated linoleic acids: Are they beneficial or detrimental to health? Prog. Lipid Res. 43:553-587. https://doi.org/10.1016/j.plipres.2004.08.002. 